\title{
Structure of Mitochondria and Vacuoles of Candida utilis and Schizosaccharomyces pombe Studied by Electron Microscopy of Serial Thin Sections and Model Building
}

\author{
By M. T. DAVISON AND P. B. GARLAND \\ Department of Biochemistry, Medical Sciences Institute, University of Dundee, \\ Dundee DDI $4 H N$
}

(Received I7 June 1976; revised 6 August 1976)

SUMMAR Y

The structure of mitochondria and of vacuoles in Candida utilis and Schizosaccharomyces pombe has been studied by electron microscopy of serial thin sections and subsequent model building. The models of the two cells of $C$. utilis which were studied confirmed our earlier findings, made by high voltage electron microscopy of thick sections, that there is a single, branched and continuous mitochondrial network in the cell (Davison \& Garland, 1975). A model of a $S$. pombe cell showed that the mitochondrial structure was far more continuous than expected from inspection of thin sections, there being but two large and two small mitochondria. The models demonstrated that the few large vacuoles in $C$. utilis were interconnected into a single cluster, whereas in $S$. pombe there were two separate complexes of interconnected vacuoles towards each pole of the cell.

\section{INTRODUCTION}

Electron microscopy of random thin sections of eukaryotic cells such as yeasts and algae gives inadequate visualization of the three-dimensional arrangement of intracellular contents. Two methods are available for describing three-dimensional intracellular structure. One method involves reconstruction of models from serial thin sections and has been applied to Pityrosporum orbiculare (Keddie \& Barajas, 1969), Chlamydomonas reinhardii (Arnold et al., 1972), Saccharomyces cerevisiae (Hoffmann \& Avers, 1973; Grimes, Mahler \& Perlman, 1974), Euglena gracilis (Osafune, 1973), Chlorella fusca (Atkinson, John \& Gunning, 1974) and Polytomella agilis (Burton \& Moore, 1974). The other method directly visualizes most or all of the cell up to a thickness of $\mathrm{r}$ to $3 \mu \mathrm{m}$ by use of high voltage electron microscopy (h.v.e.m.) (Davison \& Garland, 1974, I975; Paulin, 1975). These two methods are complementary because serial sectioning examines a few cells in great detail for a given expenditure of time and effort whereas h.v.e.m. of thick sections examines a great number of cells but in less detail because overlapping structures obscure each other.

The purpose of this work was to confirm and extend by serial sectioning and model building our earlier description of mitochondrial structure in the budding yeast $C$. utilis obtained by h.v.e.m. of thick sections (Davison \& Garland, 1974, 1975). A comparative study of the fission yeast Schizosaccharomyces pombe also seemed desirable, particularly in view of the interest in this yeast as a model for studying the cell division cycle of eukaryotic cells. Unfortunately, our attempts to study $S$. pombe by h.v.e.m. of thick sections have so far been frustrated by poor contrast. We have therefore made a model of one cell from 
serial thin sections of $S$. pombe, and find that the numerous mitochondrial profiles seen in these sections are largely continuous with each other. We also describe continuity of vacuolar structures.

\section{METHODS}

Candida utilis strain 193, from the National Collection of Yeast Cultures, Nutfield, Surrey, and Schizosaccharomyces pombe strain $97^{2 \mathrm{~h}^{-}}$, from Dr David Lloyd, Department of Microbiology, University College, Cardiff, were maintained as stock cultures on solid media at $4{ }^{\circ} \mathrm{C}$ and periodically subcultured. Initial cultures for inoculation of larger cultures were grown from the stock cultures in $100 \mathrm{ml}$ glucose-yeast medium (Conti \& Naylor, I959) at $30{ }^{\circ} \mathrm{C}$ for $24 \mathrm{~h}$, aerobically, with shaking. Larger scale cultures were made aerobically at $30^{\circ} \mathrm{C}$ in $500 \mathrm{ml} 0.5 \%$ (v/v) glycerol medium (Light \& Garland, I97I) for C. utilis and I $\%(\mathrm{w} / \mathrm{v})$ glucose medium (Mitchison, 1970 ) for $S$. pombe. The cells of $C$. utilis were harvested, by centrifuging, from the exponential phase of batch culture and they were then separated into size classes corresponding to stages of their life-cycle by the rate zonal centrifugation procedure of Poole, Lloyd \& Kemp (1973). Schizosaccharomyces pombe was harvested, by centrifuging, from the early stationary growth phase $(25 \mathrm{~h}$ culture), when the glucose concentration of the culture medium had dropped to less than $0.01 \%(\mathrm{w} / \mathrm{v})$ and the cytochrome concentration of the cells, as determined spectrophotometrically (Haddock \& Garland, 1971), showed that mitochondrial synthesis was derepressed.

For electron microscopy, the cells were fixed with $2.5 \%(\mathrm{w} / \mathrm{v})$ glutaraldehyde in $0 . \mathrm{I} \mathrm{M}$ sodium cacodylate buffer $\mathrm{pH} 7.0$ for $2 \mathrm{~h}$, and then treated with $2 \%$ (w/v) $\mathrm{KMnO}_{4}$ as described for lead citrate staining by Davison \& Garland (1975).

After fixation the cells were embedded in either Spurr's resin (Spurr, 1969) or araldite (Luft, I96I) modified for serial sectioning (H. Eichelberger, personal communication) and sectioned with a Reichert $\mathrm{OMU}_{3}$ ultramicrotome using a diamond knife. Serial sections, each about $80 \mathrm{~nm}$ thick, were collected as described by Sjöstrand (1967) and stained with lead citrate (Reynolds, I963). Electron micrographs were recorded with an AEI 8oI electron microscope operated at 60 or $80 \mathrm{kV}$ accelerating voltage. High voltage electron micrographs of thick sections of C. utilis were taken as described by Davison \& Garland (1975).

Three-dimensional models were constructed from serial thin sections essentially as described by Atkinson et al. (I974), using I I.5 mm thick expanded polystyrene sheeting. The models for $C$. utilis were made at $50000 \times$ actual cell size, and that for $S$. pombe at $136000 \times$. To make these models we assigned the larger and vesicular intracellular profiles of membranous structures into one of three categories: nuclear, mitochondrial and vacuolar. The vacuolar category was subdivided into electron-opaque and electron-transparent vacuoles in $S$. pombe. Recognition of the nuclear membrane was unambiguous. Mitochondrial profiles were identified as such by their cristae. The vacuoles in $C$. utilis were readily distinguished from mitochondria, although in $S$. pombe the distinction was sometimes less obvious and where a serial run of mitochondrial profiles appeared to be separated by a vacuolar profile, it was assumed that the assignment to the vacuolar profile was incorrect and it was therefore revised.

\section{RESULTS}

The three-dimensional structure of mitochondria and vacuoles in C. utilis

Models were made from serial thin sections of two cells. One cell was from the fraction of smallest cells collected by rate zonal centrifugation and was representative of young, 


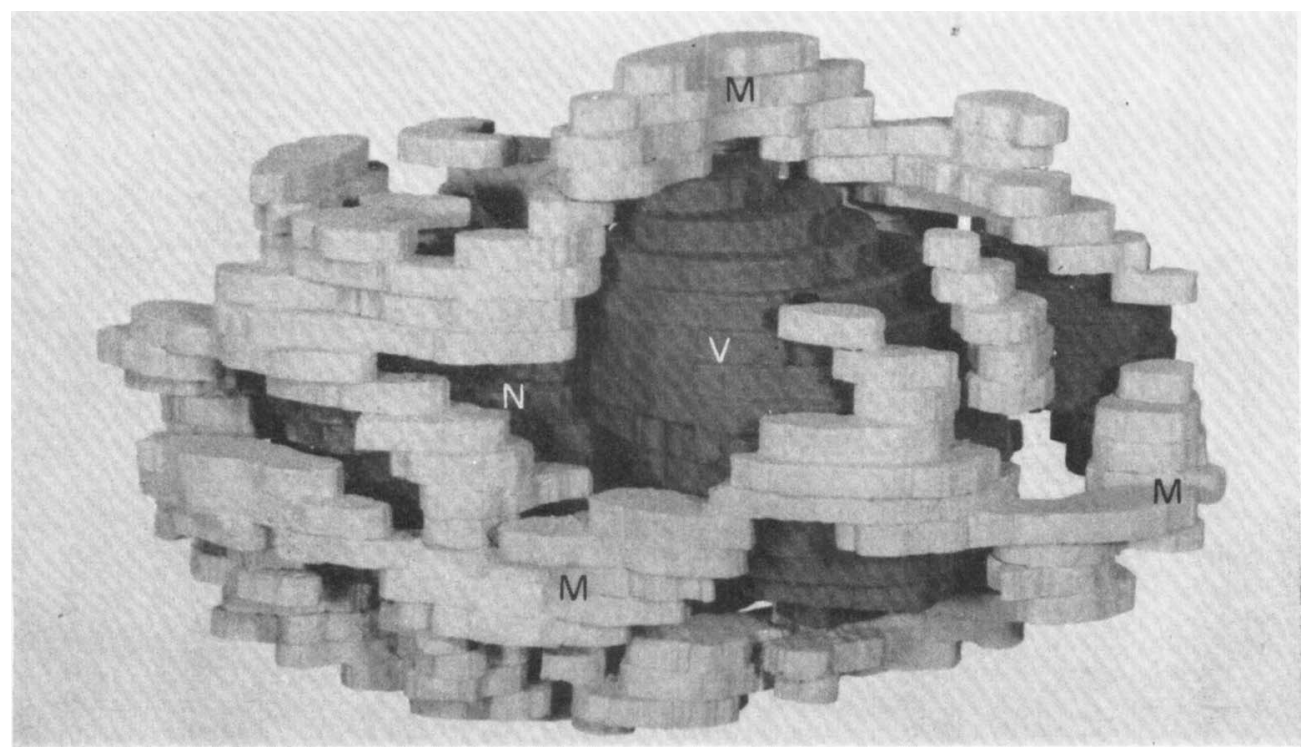

Fig. 1. Polystyrene reconstruction from serial thin sections $(75 \mathrm{~nm})$ of batch-grown $C$. utilis at an early stage in the life-cycle. Mitochondria (M) form a single branched network overlying the nucleus (N) and vacuoles (V).

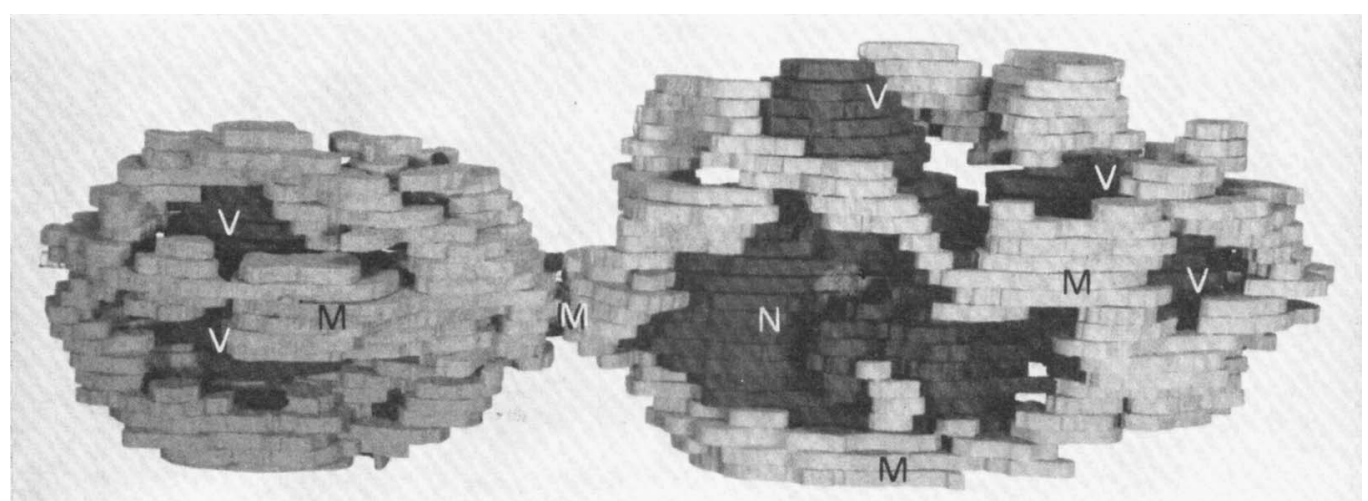

Fig. 2. Polystyrene reconstruction from serial thin sections $(75 \mathrm{~nm})$ of batch-grown C. utilis at a late stage in the life-cycle. Mitochondria (M) form a single branched interconnecting network overlying the nucleus $(N)$ and vacuoles (V) in the mother cell (right) and daughter cell (left).

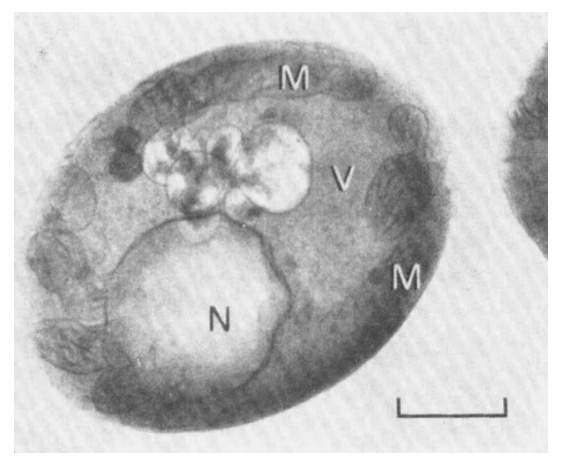

Fig. 3. Thick section ( $\mu \mathrm{m}$ ) of a chemostat-cultured, glycerol-limited $C$. utilis cell, stained with lead citrate. The section shows a cluster of rounded vacuoles (V) above the nucleus (N) and a number of apparently unconnected mitochondria (M) around the periphery of the cell. Accelerating voltage $\mathrm{I} 000 \mathrm{kV}$. Bar marker represents $\mathrm{I} \cdot 0 \mu \mathrm{m}$. 


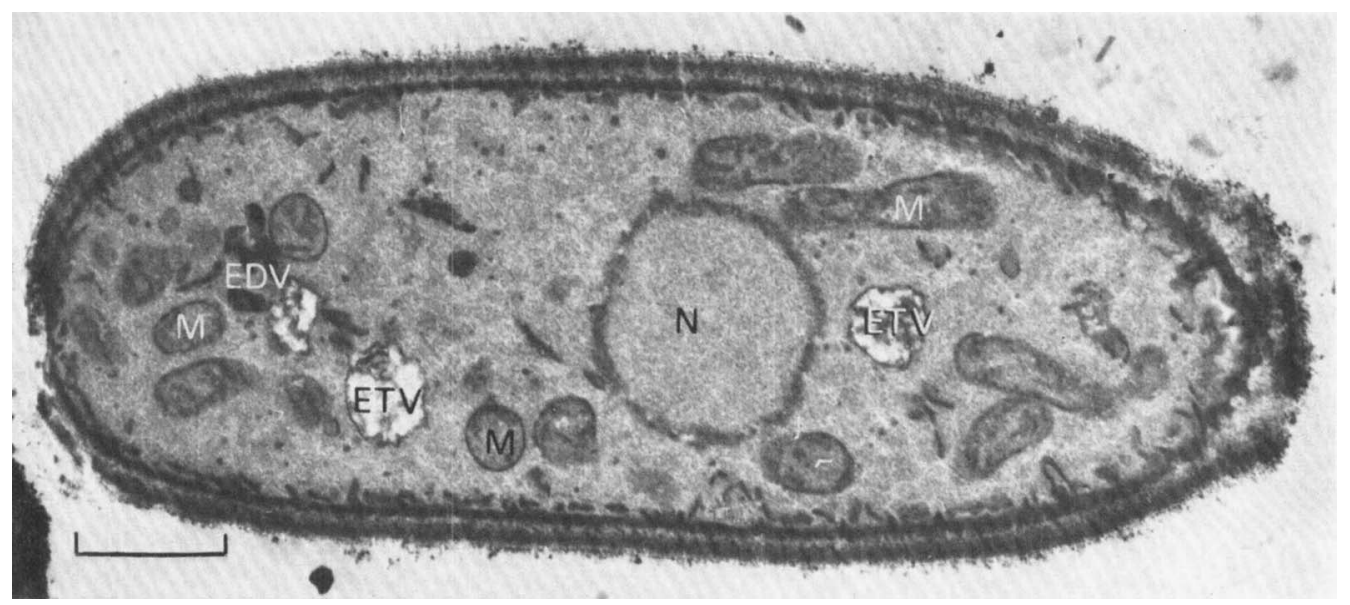

Fig. 4. Thin section $(85 \mathrm{~nm})$ of a batch-cultured $S$. pombe cell at approximately 0.6 of the cell cycle, harvested in early stationary phase. This is one of 34 sections from which the model was constructed. Mitochondrial profiles (M) containing cristae are seen at either end of the cell together with electrondense vacuoles (EDV) and electron-transparent vacuoles (ETV). The nucleus (N) is placed centrally. Accelerating voltage $80 \mathrm{kV}$. Bar marker represents $\mathrm{I} \cdot 0 \mu \mathrm{m}$.

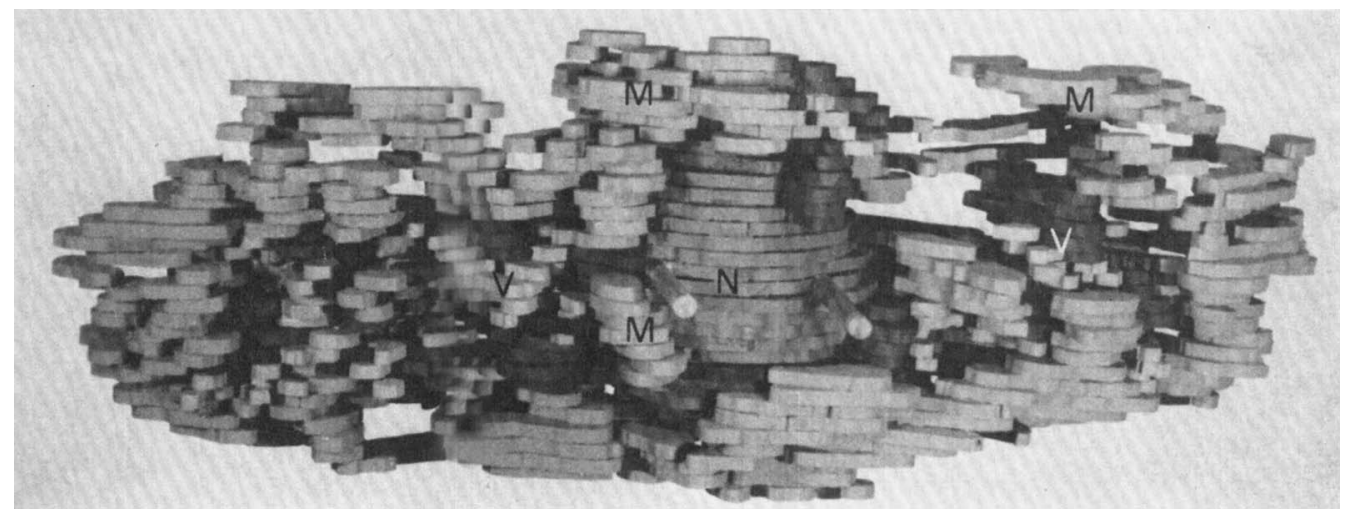

Fig. 5. Polystyrene reconstruction from serial thin sections $(85 \mathrm{~nm})$ of a $S$. pombe cell at approximately 0.6 of the cell cycle, harvested in stationary phase (glucose derepressed).

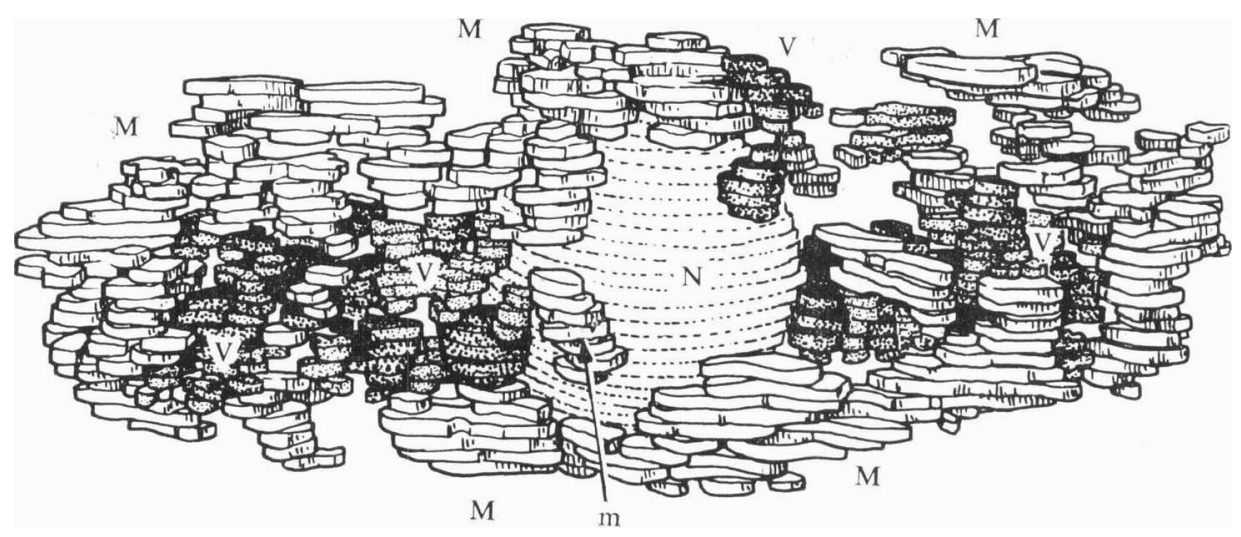

Fig. 6. Graphic representation of the model described in Fig. 5. showing two multi-lobed vacuolar complexes $(\mathrm{V})$ sited either side of the nucleus $(\mathrm{N})$. Mitochondria $(\mathrm{M})$ form two continuous reticula except for two small pieces (m). 
newly budded cells. The other cell was from the fraction of largest cells and was representative of cells with buds. In both cases the models (Figs I and 2) showed that there was only one mitochondrion per cell, and that the mitochondrion forms a peripherally placed reticulum. Even in the budding cell (Fig. 2) only one mitochondrion was present, extending from the mother into the daughter cell and preceding the appearance of a nucleus in the latter.

Vacuoles seen as separate structures in thin sections were found to be connected into a cluster in the models. The vacuolar cluster was clearly demonstrated by h.v.e.m. study of thick sections, as shown in Fig. 3. The appearance of the vacuole cluster suggests that there is a single continuous multi-lobed structure, rather than a clump of otherwise separate vacuoles.

\section{The three-dimensional structure of mitochondria and vacuoles in S. pombe}

A typical electron micrograph of a thin section of an early stationary phase cell is shown in Fig. 4. There is little in the appearance of the mitochondrial or vacuolar structures to suggest that they might form part of larger continuous structures. However, construction of a model from serial thin sections showed that there is an extensive and largely continuous mitochondrial reticulum which forms two large separate parts centred at opposite ends of the cell (Figs 5 and 6). Two further separate, but very much smaller mitochondria were also found.

The vacuoles formed two multi-lobed complexes, one towards each end of the cell. Both electron-transparent and electron-opaque vacuoles contributed to the complexes. The lumina of the vacuoles were continuous throughout the complex irrespective of whether these contents were electron-opaque or electron-transparent. Two or three smaller vacuoles were unconnected with, and lay separately from, the main complexes. As noted by Heslot, Goffeau \& Louis (1970), the vacuoles touched the nuclear membrane in places. The length of the sectioned cell was about $9 \mu \mathrm{m}$, and this, with the presence of a centrally placed spherical nucleus, indicates that the cell was about 0.6 of the way through the cell division cycle, by which time mitochondrial growth is essentially complete (Osumi \& Sando, I969).

\section{DISCUSSION}

\section{Mitochondrial structure}

The models of $C$. utilis confirm our earlier conclusion that there is a mitochondrial reticulum in this species of yeast, and identify a single continuous mitochondrial reticulum per cell. In $S$. pombe, at least in the cell studied, we again found a mitochondrial reticulum though not as continuous as in $C$. utilis, there being two large reticular structures and two small rounded mitochondria. The finding of a mitochondrial reticulum in the fission yeast $S$. pombe poses questions about the timing of mitochondrial division, and the fact that there were two separate mitochondrial reticula at opposite ends of the cell could be interpreted as indicating that mitochondrial division had preceded nuclear division in the cell cycle.

The functional significance of a mitochondrial reticulum is obscure, particularly in view of the fact that the reticulum is not constantly present in all yeast species (Grimes et al., I974; Rosen et al., 1974). A possible consequence of a mitochondrial reticulum concerns intracellular energy transmission, given that the separate oxidative and phosphorylative enzymes of oxidative phosphorylation are coupled to each other by an energized state capable of spreading laterally throughout the inner mitochondrial membrane. It is immaterial whether the energized state is a proton-motive force (Mitchell, I966), an intra-membrane 
charge separation (Williams, I96I) or a conformational state (Boyer, 1975), provided that it is sufficiently mobile. In each case, the mechanism of oxidative phosphorylation would permit respiratory chain activity at one part of the mitochondrial reticulum to drive ATP synthesis at another.

\section{Vacuolar structure}

The finding that vacuoles were in multi-lobed clusters or complexes was unexpected. The appearance of a continuous membrane with distensions into vacuoles of differing sizes suggests that new vacuolar membrane arises from the extension of pre-existing vacuole. The two complexes of vacuoles at opposite ends of the $S$. pombe cell would then provide a mechanism for apportioning vacuoles between the two cells formed at division. Presumably a different mechanism operates in the budding yeast $C$. utilis where distinctive cell poles and a dual location for vacuolar clusters are absent.

This work was generously supported by the Medical Research Council. We are indebted to Professor P. R. Swann of the Department of Metallurgy, Imperial College of Science and Technology, London, for access to the AEI EM 7 high voltage electron microscope, and to Dr E. P. Butler, Dr R. K. Poole, Mr J. Woodall, Mr R. Doole and Mr W. Bishop for advice and help. We are grateful to Mrs E. Lloyd-Davies of the Department of Anatomy, Dundee University, for her cooperation, and to Mrs M. Hardie and Mr D. Coutie for technical assistance. We also thank Miss M. Benstead for her artwork.

\section{REFERENCES}

Arnold, C. G., Schimmer, O., Schotz, F. \& Bathelt, H. (1972). Die Mitochondrien von Chlamydomonas reinhardii. Archiv für Mikrobiologie 81, 50-67.

Atkinson, A. E., John, P. C. L. \& GunNING, B. E. S. (1974). The growth and division of the single mitochondrion and other organelles during the cell cycle of Chlorella studied by quantitative stereology and three-dimensional reconstruction. Protoplasma 81, 77-I09.

BOYER, P.D. (1975). Energy transduction and proton translocation by adenosine triphosphatase. FEBS Letters 5o, $91-97$.

Burton, M.D. \& Moore, J. (1974). The mitochondrion of the flagellate Polytomella agilis. Journal of Ultrastructure Research 48, 414-419.

CONTI, S. F. \& NAYLOR, H. B. (I959). Electron microscopy of ultrathin sections of Schizosaccharomyces octosporus. Journal of Bacteriology 78, 868-877.

Davison, M. T. \& Gariand, P. B. (1974). The intracellular morphology of yeast mitochondrial membranes: studies with high voltage electron microscopy. Proceedings of the Society for General Microbiology $\mathbf{r}$, 4I.

Davison, M. T. \& GaRLAND, P. B. (1975). Mitochondrial structure studied by high voltage electron microscopy of thick sections of Candida utilis. Journal of General Microbiology 91, 127-138.

Grimes, G. W., Mahler, H. R. \& Perlman, P. S. (1974). Nuclear gene dosage effects on mitochondrial mass and DNA. Journal of Cell Biology 6r, 565-574.

HADDOCK, B. A. \& GaRLAND, P. B. (I97I). Effect of sulphate-limited growth on mitochondrial electron transfer and energy conservation between reduced nicotinamide adenine dinucleotide and the cytochromes in Torulopsis utilis. Biochemical Journal 124, 155-170.

Heslot, H., GoffeAu, A. \& Louis, C. (1970). Respiratory metabolism of a 'petite negative' yeast Schizosaccharomyces pombe $972 \mathrm{~h}^{-}$. Journal of Bacteriology I04, 473-48I.

HoffMANN, H. P. \& Avers, C. J. (1973). Mitochondrion of yeast: ultrastructural evidence for one giant branched organelle per cell. Science 181, 749-751.

KedDie, F. M. \& BarajaS, L. (I969). Three-dimensional reconstitution of Pityrosporum yeast cells based on serial section electron microscopy. Journal of Ultrastructure Research 29, 260-275.

Light, P. A. \& Garland, P. B. (1971). A comparison of mitochondria from Torulopsis utilis grown in continuous culture with glycerol, iron, magnesium or phosphate as the growth limiting nutrient. Biochemical Journal 124, 123-134.

LUFT, J. H. (1961). Improvements in expoxy resin embedding methods. Journal of Biophysical and Biochemical Cytology 9, 409. 
Mitchell, P. (1966). Chemiosmotic Coupling in Oxidative and Photosynthetic Phosphorylation. Bodmin, Cornwall: Glynn Research Ltd.

Mitchison, J. M. (1970). Physiological and cytological methods for Schizosaccharomyces pombe. Methods in Cell Physiology 4, I $3 \mathrm{I}-165$.

OSAFUNE, T. (1973). Three-dimensional structure of giant mitochondria, dictyosomes and concentric lamellar bodies formed during the cell cycle of Euglena gracilis $(\mathrm{Z})$ in synchronous culture. Journal of Electron Microscopy 22, 5I-6I.

Osumi, M. \& SANDO, N. (I969). Division of yeast mitochondria in synchronous culture. Journal of Electron Microscopy 18, 47-56.

Paulin, J. R. (1975). The chondriome of selected trypanosomes. A three-dimensional study based on thick sections and high voltage electron microscopy. Journal of Cell Biology 66, 404-413.

Poole, R. K., Lloyd, D. \& KeMP, R. B. (1973). Respiratory oscillations and heat evolution in synchronously dividing cultures of the fission yeast Schizosaccharomyces pombe $972 \mathrm{~h}^{-}$. Journal of General Microbiology 77, 209-220.

REYNOLDS, E. S. (1963). The use of lead citrate at high pH as an electron opaque stain in electron microscopy. Journal of Cell Biology 17, 209-2 2.

Rosen, D., Edelman, M., Galun, E. \& Danon, D. (1974). Biogenesis of mitochondria in Trichoderma viride: structural changes in mitochondria and other spore constituents during conidium maturation and germination. Journal of General Microbiology 83, $3 \mathrm{I}-49$.

Suöstrand, F. S. (1967). Electron Microscopy of Cells and Tissues, vol. I. New York and London: Academic Press.

SPURR, A. R. (1969). A low viscosity epoxy resin embedding medium for electron microscopy. Journal of Ultrastructure Research 26, 31-43.

Williams, R. J. P. (I96I). Possible functions of chains of catalysts. Journal of Theoretical Biology 1, I-I7. 